\title{
Overview of Coronavirus Behavior in Hill State Uttarakhand and Most Affected States in India
}

\author{
Abhinav Gaur ${ }^{1}$, Om Prakash ${ }^{1 *}$, Hem C Joshi², Ajay Kumar ${ }^{3}$, \\ Anil Verma ${ }^{3}$, S. K. Guru ${ }^{2}$ and Shyam N. Nautiyal ${ }^{4}$ \\ ${ }^{1}$ Department of Applied Chemistry Sardar Bhagwan Singh Post Graduate Institute of \\ Biomedical Sciences and Research, Balawala Dehradun, Uttarakhand(U.K.), India-248161 \\ ${ }^{2}$ Department of Plant Physiology, ${ }^{3}$ Department of Chemistry, College of Basic Sciences and \\ Humanities, G.B. Pant University of Agriculture and Technology, Pantnagar, Uttarakhand \\ (U.K.), India-263145 \\ ${ }^{4}$ Hydro Processing Renewable Fuel Area and Biofuel Division, \\ CSIR-IIP Dehradun, 248001), India \\ *Corresponding author
}

\begin{tabular}{|c|}
\hline Keywords \\
\hline $\begin{array}{l}\text { Coronavirus, } \\
\text { Covid- } 19 \text {, Fatality } \\
\text { rate, Respiratory } \\
\text { Syndrome, } \\
\text { Recovery rate }\end{array}$ \\
\hline Article Info \\
\hline $\begin{array}{l}\text { Accepted: } \\
22 \text { June } 2020 \\
\text { Available Online: } \\
10 \text { July } 2020\end{array}$ \\
\hline
\end{tabular}

A B S T R A C T

Recently in 2019, the worst form of virus called "Covid-19" attacked human population. First infection worldwide was found in Wuhan, China in month of November 2019. Since then Covid-19 is explosively spreading through-out the globe with more than 5 million positive cases and more than $300 \mathrm{k}$ deaths. Understanding the medical concept, Coronavirus disease 2019 is an infectious disease caused by severe acute respiratory syndrome coronavirus 2 also called as SARS-CoV-2. The symptoms of which includes fever, cough, fatigue, shortness of breath, and loss of smell and taste. In most of cases it result in mild symptoms which later turns to acute respiratory distress syndrome (ARDS) trigger s a cytokine storm, multi-organ failure, septic shock, and blood clots. In this study we analyzed how corona virus is targeting different states and union territories of India. We high tailed the fatality rate that means the percentage of deaths caused with respect to number of people infected by disease state wise to understand performance of state population and their ability to tolerate infection. We also compared fatality rate of Indian states with states of other countries having identical climatic conditions.

\section{Introduction}

Coronavirus belongs to Coronaviridae family. Basically, this family includes enveloped, positive sense, single-stranded RNA viruses having viral genome of 26 to 32 kilo bases in length. The family consist many corona viruses which mainly target mammals and birds, in human species they mostly attack on respiratory system and cause lung related disorders.

Severe Acute Respiratory Syndrome also known as "SARS" was the first respiratory infection that highlighted the Corona viridae family, it was spread from China, Asia in early 2000s. After "SARS"; Middle East Respiratory Syndrome also known as "The 
MERS" targeted human species and caused lung related problems in population of Middle-east, Asia.

A submicroscopic infectious agent that lack ability to self-replicate in a medium free of life but actively replicates inside living cell is called as a virus. The infections caused by viruses are called as viral diseases. A virus may have RNA or DNA as genetic material, the nucleotide present in virus may be single or double stranded, infection causing viruses are mostly have RNA as genetic material. Although a virus only consists of a protein coat and genome, it lacks in functional organelles and it also do not perform any living function but once it enters inside the living cell, it is capable to control cell's machinery and direct synthesis of virus's genome and protein. Thus, it thrives within a living cell of human or animal and even in plants to replicate its own kind. Most primitive virus generally consists of RNA or DNA genome that can encode 4 to 5 proteins only. Some typical virus may consist enough RNA or DNA genome to encode for more than 100 proteins. In past 20 years, different viral diseases came into discussion and research for science community. The severe acute respiratory syndrome coronavirus (SARS-CoV) affected human population in 2002 and 2003, H1N1 influenza made a hit on human population in 2009. Recently, the Middle East respiratory syndrome coronavirus (MERS-CoV) was first identified in 2012. And meanwhile Covid-19 (SARS$\mathrm{CoV}-2$ ) emerged as an epidemic disease.

In November 2019 first case of corona was reported in China, Asia. In less than a year the virus spread globally and reached 58, 03,416 cases worldwide till $29^{\text {th }}$ of May 2020. In India the first case was reported $30^{\text {th }}$ January 2020 and till $29^{\text {th }}$ of May 2020 it has spread to $1,65,799$ individuals. And hence it is one of the most spreadable viral diseases human has ever encountered in history of medical science.

Corona viruses, is a genus of the Corona viridae family. The family consist of enveloped viruses with a large plus-strand RNA genome. The genomic RNA is $27-32 \mathrm{~kb}$ in size, it is capped and polyadenylated. Three serologically distinct groups of coronaviruses are known. In each group, viruses are characterized by their host range and by their genome sequence. Different groups of these viruses have been identified in mice, rats, chickens, turkeys, swine, dogs, cats, rabbits, horses, cattle and humans.[1]

In Corona viridae family, genus Beta conora virus exists that include sub-genius Sarbecovirus. This sub-genius includes the specie called severe acute respiratory syndrome coronavirus (SARS-CoV). This specie is known to cause severe acute respiratory syndrome which is basically a respiratory related disorder in human species. The new form of severe acute respiratory syndrome coronavirus (SARS$\mathrm{CoV}$ ) identified as severe acute respiratory syndrome coronavirus-2 (SARS$\mathrm{CoV}-2$ ) which is currently under investigation is known to spread Covid-19 nowadays. [2]

\section{Genome and Morphology}

The SARS-CoV corona viruses are enveloped viruses having positive-sense and consisting of a single stranded RNA genome. The genome is of about $30 \mathrm{~kb}$. It has 14 open Viral genome of SARS CoV viruses has a 5' methylated cap with 256 nucleotides and a 3' polyadenylated tail with 342 nucleotides, this arrangement allows positive-sense RNA genome to be directly translated by the host cell's ribosome after viral entry. [3]

An outer coat with finger like projections and RNA genome are two key morphological 
characters of Coronaviridae family. Further morphological studies on SARS-CoV viruses highlighted presence of a large pleomorphic spherical particles with bulbous surface projections. The size of the virus is in the range of $80-90 \mathrm{~nm}$. The viral envelope consists of a lipid bilayer where the membrane (M), envelope (E) and spike (S) proteins are present. The spike proteins have the bulbous surface projections. The spike protein's interaction with its complement host cell receptor is central in determining the tissue tropism, infectivity, and species range of the virus. Inside the envelope, there is the nucleocapsid, which is formed from multiple copies of the nucleocapsid $(\mathrm{N})$ protein, which are bound to the positive-sense singlestranded $(\sim 30 \mathrm{~kb})$ RNA genome in a continuous beads-on-a-string type conformation. The lipid bilayer envelope, membrane proteins, and nucleocapsid protect the virus when it is outside the host.

\section{Symptoms and Transmission}

The symptoms of SARS-CoV-2 include fever, cough, fatigue, shortness of breath, and loss of smell and taste. In most of cases it results in mild symptoms which later turns to acute respiratory distress syndrome (ARDS) triggers a cytokine storm, multi-organ failure, septic shock, and blood clots.[6] According to World Health Organization, "the most common symptoms of COVID-19 are fever, dry cough, and tiredness. Other symptoms that are less common and may affect some patients include aches and pains, nasal congestion, headache, conjunctivitis, sore throat, diarrhea, loss of taste or smell or a rash on skin or discoloration of fingers or toes." The time between exposure to COVID-19 and the moment when symptoms start is commonly around five to six days but can range from $1-$ 14 days. According to World Health Organization, most people who gain infection easily recover from the disease without needing clinical treatment. And only 1 out of every 5 people who gets infected with COVID-19 becomes seriously ill and develops difficulty breathing. The critical illness is mainly circled to older people, and those with underlying medical problems like high blood pressure, heart and lung problems, diabetes, or cancer. The viral infection may be asymptomatic, it is possible to identify COVID-19 infection from someone who has just has a mild cough and does not feel ill. According to World Health Organization "some reports have indicated that people with no symptoms can transmit the virus. It is not yet known how often it happens."

The disease spreads primarily from person to person through small droplets from the nose or mouth, which are expelled when a person with COVID-19 coughs, sneezes, or speaks. These droplets are relatively heavy, do not travel far and quickly sink to the ground. People can catch COVID-19 if they breathe in these droplets from a person infected with the virus. These droplets can land on objects and surfaces around the person such as tables, doorknobs and handrails. People can become infected by touching these objects or surfaces, then touching their eyes, nose or mouth.

\section{Fatality Rate and Recovery Rate of SARS- CoV-2}

Fatality rate also known as mortality rate or fatality ratio is simply a mathematical figure that represent the percentage of number of deaths of individuals caused by any disease with respect to the total number of individuals affected by disease. Case fatality rate is calculated by dividing the number of deaths from a specified disease over a defined period of time by the number of individuals diagnosed with the disease during that time; the resulting ratio is then multiplied by 100 to yield a percentage. [7] [8] Whereas the 
recovery rate is mathematical figure that represent the number of individuals successfully recovered from any disease with respect to the total number of individuals affected by disease. It is calculated by dividing the number of individuals recovered successfully from total number of individuals affected by disease, then multiplied by 100 to get percentage. [7] [8]

Till $29^{\text {th }}$ Of May 2020, approximately 58, 03, 000 cases of corona virus positive individuals were recorded around the world. Where United States of America stood as worst hit country while India was $9^{\text {th }}$ most affected country in the world with approximately $1,65,000$ cases. The recovery rate and fatality rate are calculated below.

Thus, the average recovery rate is $41.34 \%$ world wide and $43.03 \%$ in India. The recovery rate in India is slightly better than the world average. Whereas, the fatality rate of world is $6.18 \%$ while that in India it is $2.90 \%$ that means India is doing far better than world.

The data represented in above graph makes it quite clear that fatality average rate of India is half the average fatality rate of the world. But recovery is quite as same as the average.

\section{Methodology of Data Analysis}

In this study collected statistical data of Covid-19 cases worldwide using Google analyst, whereas for data related to India and states of India we used government driven application called Aarogaya Setu. We calculated the recovery rate in world, recovery rate in India, recovery rate in top 10 most affected states of India, recovery rate in Uttarakhand state, fatality rate in world, fatality rate in India, fatality rate in top 10 most affected states of India and fatality rate of Uttarakhand state.

\section{Results and Discussion}

In this study collected following data using the government driven "Aarogaya setu" application. The data includes all updated cases of corona positive individuals, all recovered individuals and all unfortunate deaths occurred till $30^{\text {th }}$ May 2020, 8:00pm as per Indian time.

Maharashtra, a state in western India is most affected with 62,228 cases and 2098 deaths. Andra Pradesh, a state in south India and Rajasthan, a state in north-western part of India has the highest recovery rate of $64.78 \%$ and $62.68 \%$ respectively. While West Bengal, a state in eastern part of India and Gujarat, a state in western part of India has worst and highest fatality rate of $6.27 \%$ and $6.15 \%$. Also, West Bengal has one of the lowest recovery rate after Bihar, a state in northcentral India.

Based on recovery rate the performance of top ten most affected states in India can be shown as - Andra Pradesh > Rajasthan > Uttar Pradesh > Tamil Nadu > Madhya Pradesh > Gujarat $>$ Delhi $>$ Maharashtra $>$ West Bengal $>$ Bihar. This typically highlights the capability of medical staff to deal with disease using drug cocktail and quarantine practices.

Above graph represent comparison between recovery rate and fatality rate in top 10 most affected states of India. Maharashtra seems to have worse affect based on both slow recovery rate and high fatality rate. West Bengal and Gujarat are also showing slow recovery based on fatality rate in the state respectively.

The average recovery rate in top 10 most affected states of India is $51.26 \%$, whereas the average recovery rate of India is $43.03 \%$ while the world average is $41.34 \%$. Based on the average recovery rate of top ten most 
affected states, Andra Pradesh, Rajasthan, Uttar Pradesh, Madhya Pradesh and Gujarat are showing more than average recovery.

The average fatality rate of top ten most affected states in India is $3.02 \%$, whereas the national average is $2.90 \%$ while the world average is $6.18 \%$. Based on average fatality rate of top 10 most affected states in India, West Bengal, Gujarat and Maharashtra are performing worse than other states.
From above Figure it is quite clear that, except Bihar and West Bengal all other top 10 most affected states of India are showing better recovery than the world average. Thus, recovery rate in West Bengal and Bihar becomes alarming concern.

Data from above figure again put light on West Bengal which is showing fatality rate higher than the world average. Whereas Gujarat is nearly showing equaWl fatality rate like the world average.

Table.1 Cases World and Cases in India till $29^{\text {th }}$ May (in Lakh)

\begin{tabular}{|l|l|l|}
\hline & \multicolumn{1}{|c|}{ Worldwide } & \multicolumn{1}{c|}{ In India } \\
\hline Total Infected & $\sim 58,03,000$ & $\sim 1,65,000$ \\
\hline Total Recovered & $\sim 23,99,000$ & $\sim 71,000$ \\
\hline Total Deaths & $\sim 3,59,000$ & $\sim 4800$ \\
\hline
\end{tabular}

(Source:https://www.mygov.in/aarogya-setu-app/)

Table.2 Percentage of Recovery and fatality cases in world and in India (till $29^{\text {th }}$ May)

\begin{tabular}{|l|l|l|}
\hline & \multicolumn{1}{|c|}{ Worldwide } & \multicolumn{1}{c|}{ In India } \\
\hline Recovery Rate & $23,99,000 / 58,03,000 \times 100=41.34 \%$ & $71,000 / 1,65,000 \times 100=43.03 \%$ \\
\hline Fatality Rate & $3,59,000 / 58,03,000 \times 100=6.18 \%$ & $4800 / 1,65,000 \times 100=2.90 \%$ \\
\hline
\end{tabular}

(Source:https://www.mygov.in/aarogya-setu-app/)

Table.3 Data of ten most affected states in India (till $30^{\text {th }}$ May)

\begin{tabular}{|l|c|c|c|c|c|}
\hline \multicolumn{1}{|c|}{ State } & $\begin{array}{c}\text { Total } \\
\text { Cases }\end{array}$ & $\begin{array}{c}\text { Total } \\
\text { Recovered }\end{array}$ & $\begin{array}{c}\text { Total } \\
\text { Deaths }\end{array}$ & $\begin{array}{c}\text { \% Recovery } \\
\text { Rate }\end{array}$ & $\begin{array}{c}\text { \% Fatality } \\
\text { Rate }\end{array}$ \\
\hline Maharastra & 62,228 & 26,997 & 2098 & 43.38 & 3.37 \\
\hline Tamil Nadu & 20,246 & 11,313 & 154 & 55.87 & 0.76 \\
\hline NCT of Delhi & 17,386 & 7846 & 398 & 45.12 & 2.28 \\
\hline Gujrat & 15,934 & 8611 & 980 & 54.04 & 6.15 \\
\hline Rajisthan & 8365 & 5244 & 184 & 62.68 & 2.19 \\
\hline Madhya Pradesh & 7645 & 4269 & 334 & 55.80 & 4.36 \\
\hline Uttar Pradesh & 7284 & 4244 & 198 & 58.26 & 2.71 \\
\hline West Bengal & 4813 & 1775 & 302 & 36.87 & 6.27 \\
\hline Andra Pradesh & 3436 & 2226 & 60 & 64.78 & 1.74 \\
\hline Bihar & 3376 & 1211 & 15 & 35.87 & 0.44 \\
\hline & Average \% & & & $\mathbf{5 1 . 2 6}$ & $\mathbf{3 . 0 2}$ \\
\hline
\end{tabular}

(Source:https://www.mygov.in/aarogya-setu-app/) 
Table.4 Data of Covid-19 in Uttarakhand State (till $30^{\text {th }}$ May)

\begin{tabular}{|c|c|c|c|c|c|}
\hline State & $\begin{array}{c}\text { Total } \\
\text { Cases }\end{array}$ & $\begin{array}{c}\text { Total } \\
\text { Recovered }\end{array}$ & $\begin{array}{c}\text { Total } \\
\text { Deaths }\end{array}$ & $\begin{array}{c}\text { \% Recovery } \\
\text { Rate }\end{array}$ & $\begin{array}{c}\text { \% Fatality } \\
\text { Rate }\end{array}$ \\
\hline Uttarakhand & 716 & 102 & 5 & 14.24 & 0.69 \\
\hline
\end{tabular}

Table.5 Data of Covid-19 in India and in Uttarakhand State (till $30^{\text {th }}$ May)

\begin{tabular}{|l|c|c|c|c|c|}
\hline \multicolumn{1}{|c|}{ Focus } & $\begin{array}{c}\text { Total } \\
\text { Cases }\end{array}$ & $\begin{array}{c}\text { Total } \\
\text { Recovered }\end{array}$ & $\begin{array}{c}\text { Total } \\
\text { Deaths }\end{array}$ & $\begin{array}{c}\text { \% Recovery } \\
\text { Rate }\end{array}$ & $\begin{array}{c}\text { \% Fatality } \\
\text { Rate }\end{array}$ \\
\hline India & $1,73,763$ & 82,370 & 4971 & 47.40 & 2.86 \\
\hline Uttarakhand & 716 & 102 & 5 & 14.24 & 0.69 \\
\hline 10 most affected states & $1,50,713$ & 73736 & 4723 & 48.92 & 3.13 \\
\hline
\end{tabular}

(Source:https://www.mygov.in/aarogya-setu-app/)

Fig.1 Schematic Diagram of the SARS-CoV genome organization (Source: BMC evolutionary biology) [3]

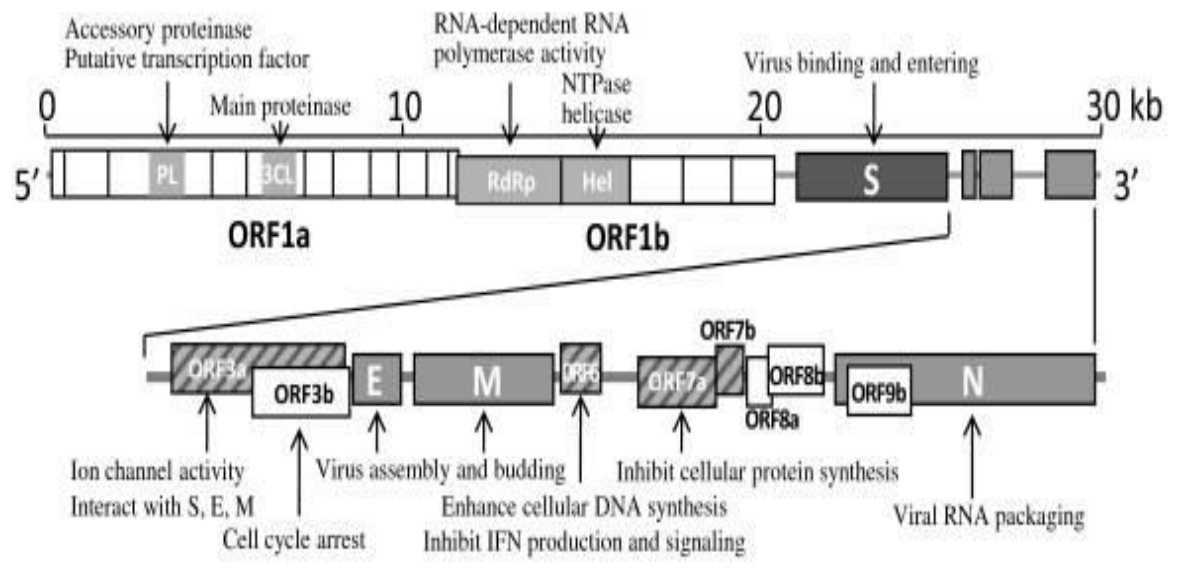

Fig.2 Schematic Diagram of Morphology of Corona virus (Source: journal of virology) [3] [4]

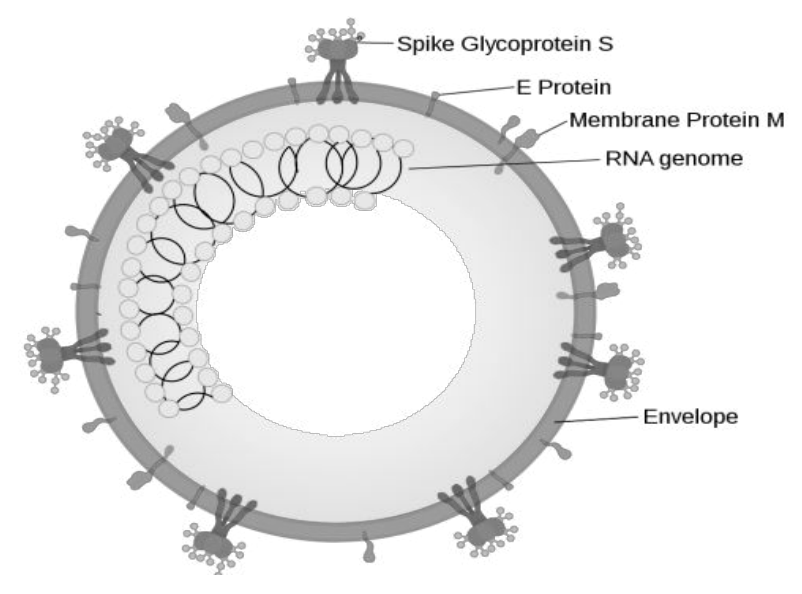


Fig.3 Cases worldwide vs Cases in India till $29^{\text {th }}$ May (in Lakh)

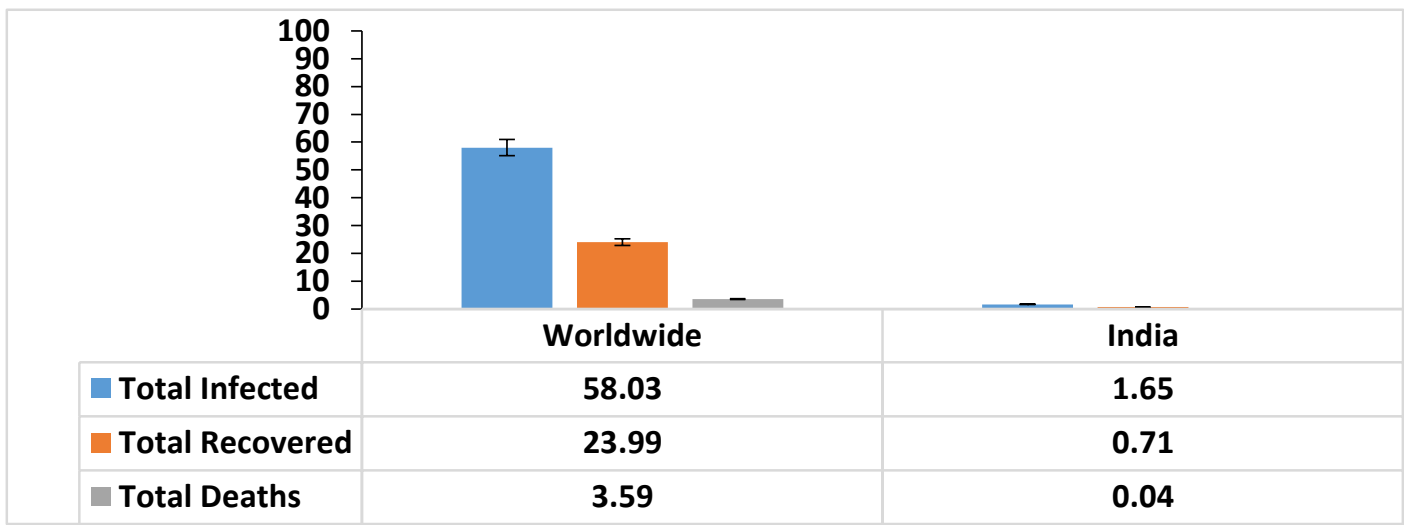

(Source:https://www.mygov.in/aarogya-setu-app/)

Fig.4 Percentage of recovery and fatality cases in World and in India till $29^{\text {th }}$ May (in Lakh)

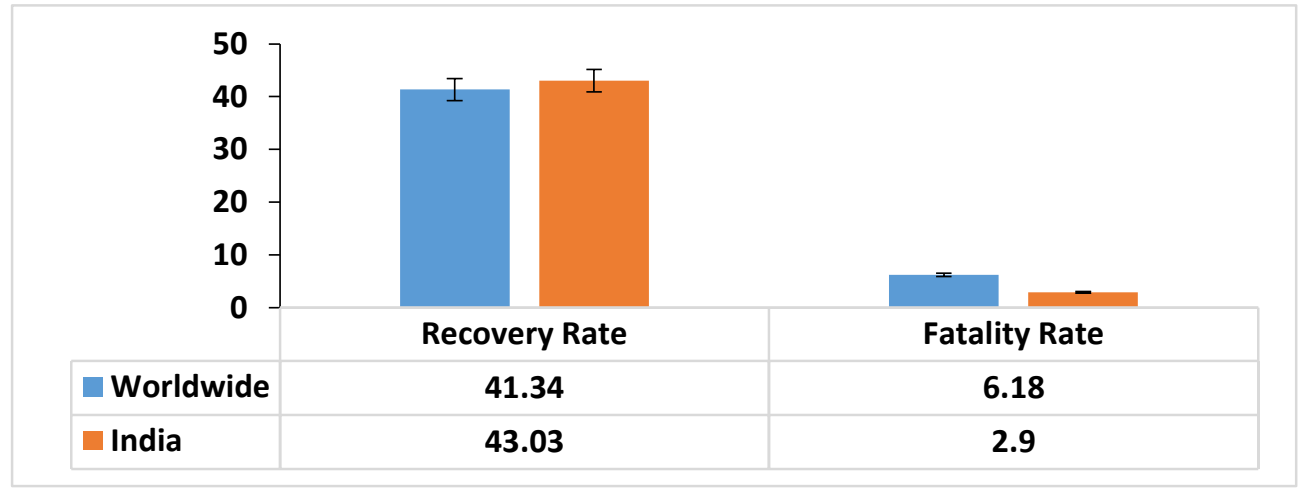

(Source:https://www.mygov.in/aarogya-setu-app/)

Fig.5 Percentage of recovery and fatality cases in 10 most affected states in India

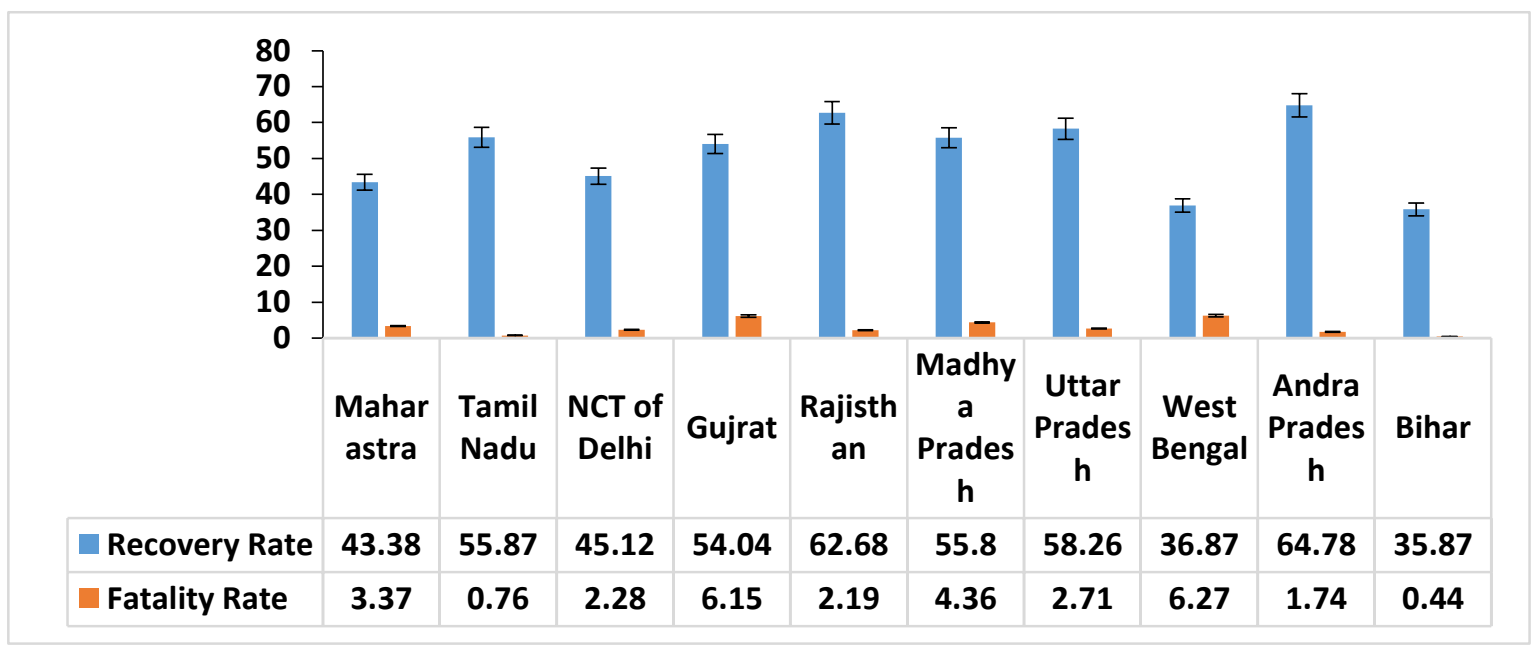


Fig.6 Percentage of recovery rate in 10 most affected states in India w.r.t. national average

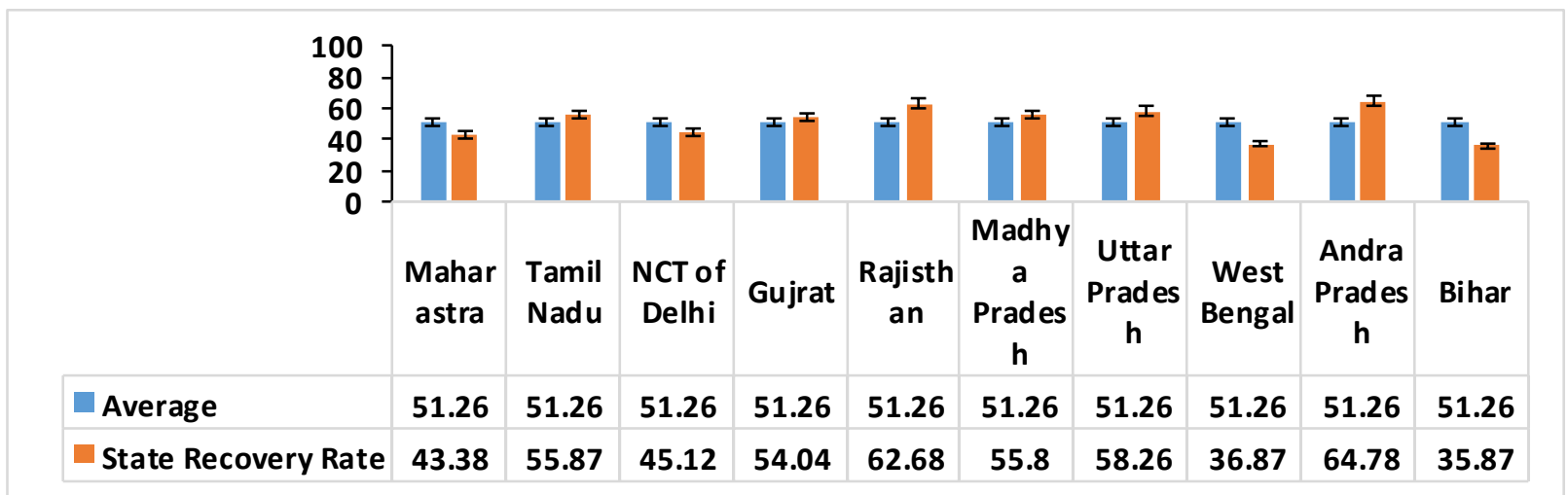

(Source:https://www.mygov.in/aarogya-setu-app/)

Fig.7 Percentage of fatality rate in 10 most affected states in India w.r.t. national average

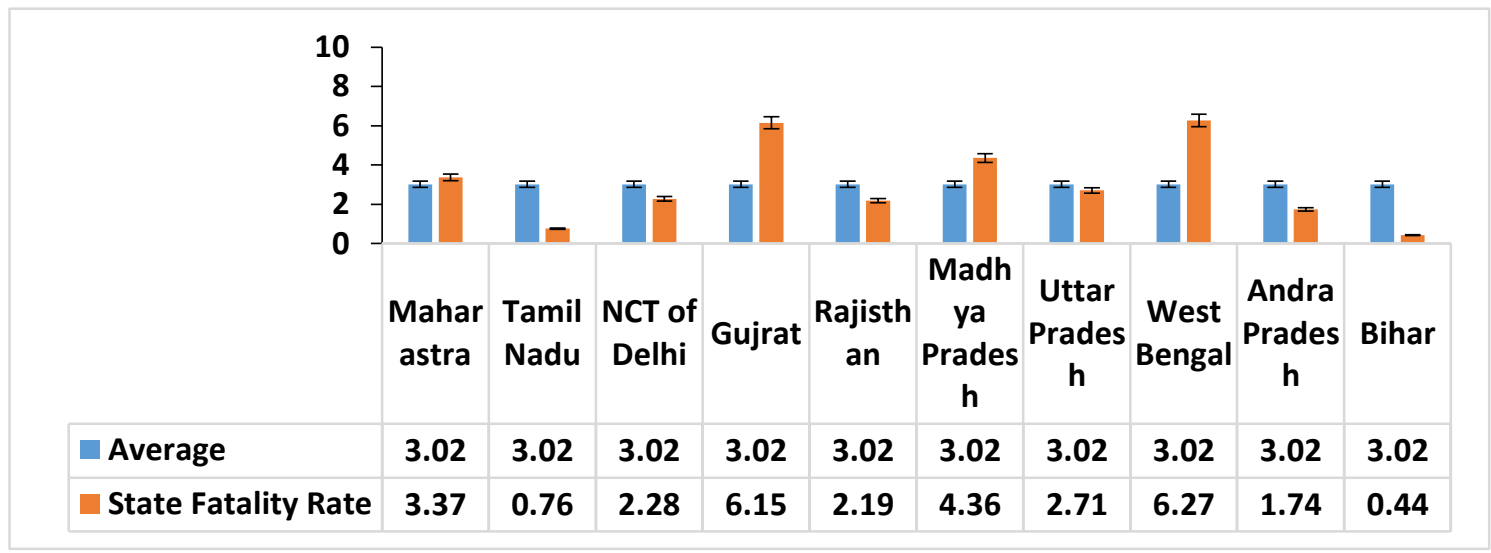

(Source:https://www.mygov.in/aarogya-setu-app/)

Fig.8 Percentage of recovery rate in 10 most affected states in India w.r.t. World average

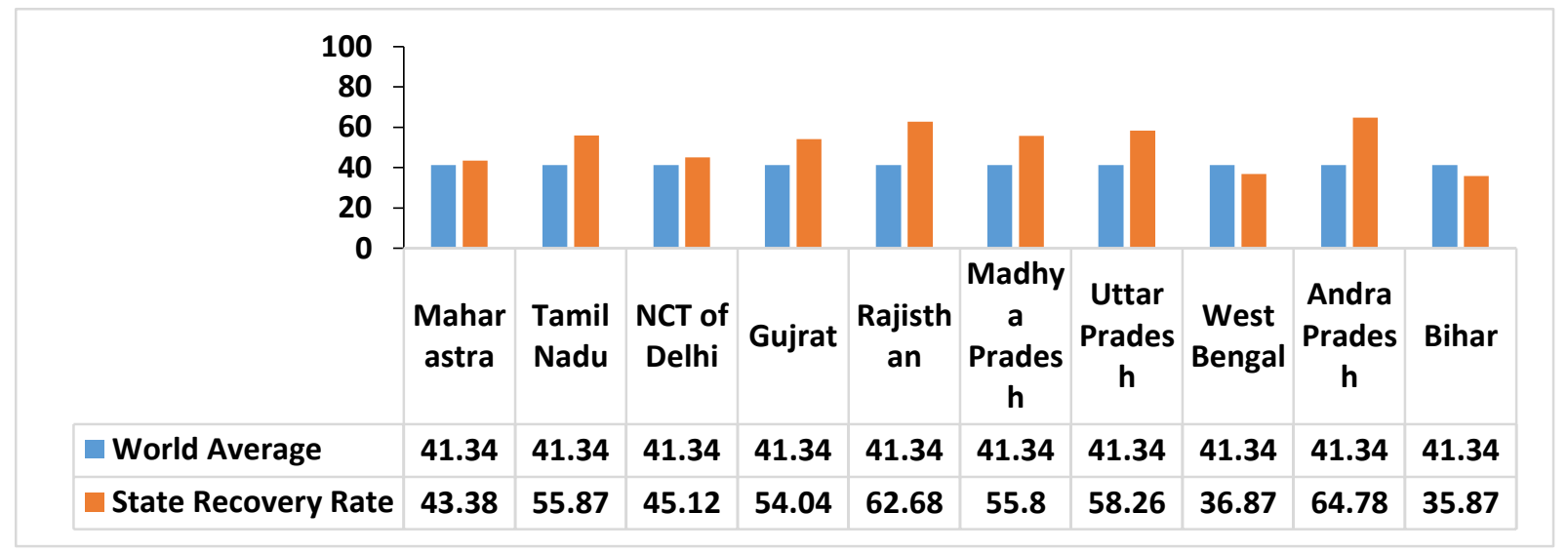

(Source:https://www.mygov.in/aarogya-setu-app/) 
Fig.9 Percentage of fatality rate in 10 most affected states in India w.r.t. World average

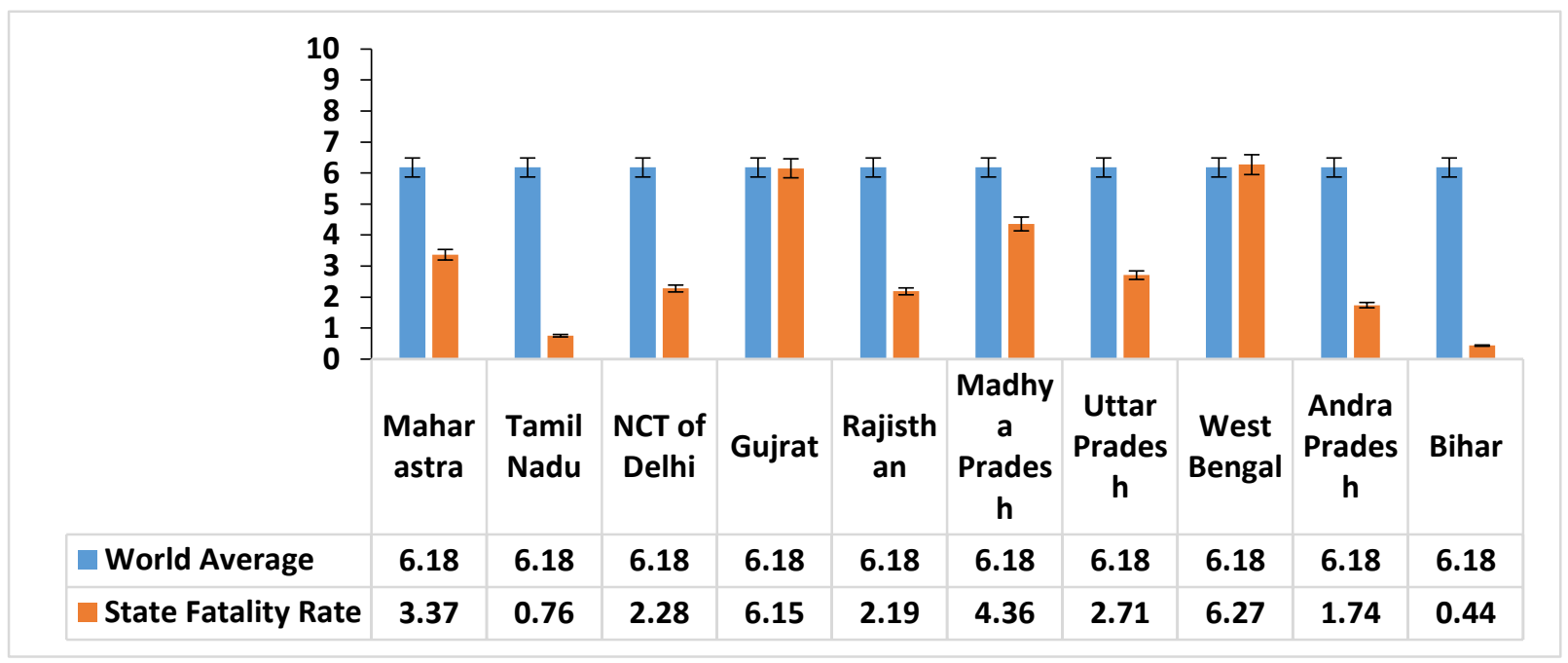

(Source:https://www.mygov.in/aarogya-setu-app/)

Fig.10 Comparisons for world, India, 10 most affected states in India and Uttarakhand State (till $30^{\text {th }}$ May)

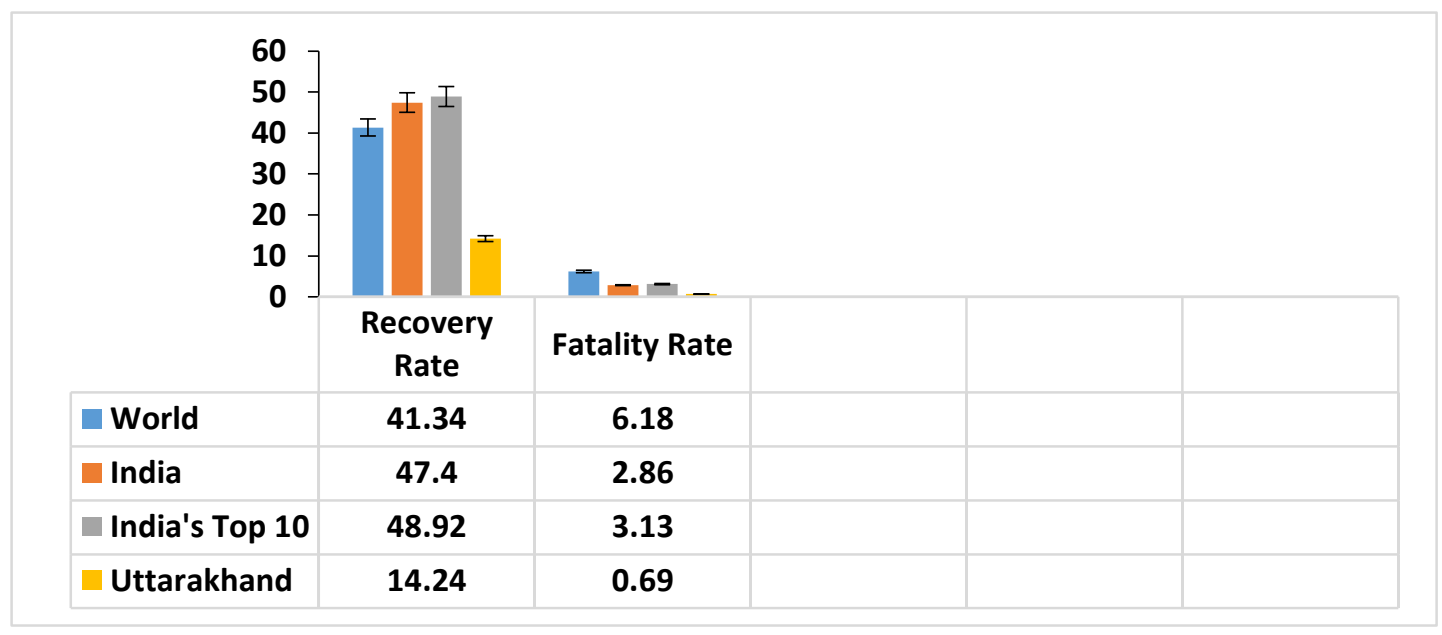

(Source:https://www.mygov.in/aarogya-setu-app/)

\section{Case Study of State Uttarakhand}

Table below represent the total data for Uttarakhand, a state in north India. Uttarakhand recorded 716 cases till $30^{\text {th }}$ May, 8:00pm which is approximately $0.41 \%$ of total cases detected in India till $30^{\text {th }}$ May, $8: 00 \mathrm{pm}$. On the other hand, Uttarakhand recorded 5 deaths only.
The recovery rate in Uttarakhand is $14.24 \%$ whereas the fatality rate in Uttarakhand is $0.69 \%$. One can see that the fatality graph is nearly invisible above. As fatality rate is quite low.

The recovery rate in Uttarakhand is extremely low as compared to recovery rate of top ten most affected states of India, as compared to national average as well as with respect to 
world average. This slow recovery rate is alarming as if the number of cases increase due to interstate or international movement, the recovery rate will create a huge issue. Uttarakhand government must focus on improving medical practices towards dealing with corona positive individuals. Better recovery rate is required by the state to stand with respect to national average. The recovery rate in Uttarakhand is far less than the recovery rate of Bihar, which is least among 10 most affected states of India. Whereas the fatality rate is quite better as compared to all other parameters we have taken in consideration.

In conclusion among top most affected states in India, West Bengal is the one which is showing alarming situation based of both slow recovery rate of $36.87 \%$ and high fatality rate of $6.27 \%$. Hence West Bengal needs to improve their medical abilities of handling corona positive individuals and saving lives of those who are at last stage. Gujarat is also showing high fatality that means, lifesaving medical services must be improved although recovery rate seems quite well. Whereas Maharashtra needs to control community spread by maintaining social distancing. Recovery rate and fatality rate are quite good in Maharashtra. While Uttarakhand needs to push towards alternate medical practice to handle corona positive individuals as the recovery rate is very alarming at meantime. Based on the average recovery rate of top ten most affected states, Andra Pradesh, Rajasthan, Uttar Pradesh, Madhya Pradesh and Gujarat are showing more than average recovery. Based on average fatality rate of top 10 most affected states in India, West Bengal, Gujarat and Maharashtra are performing worse than other states. Except Bihar and West Bengal all other top 10 most affected states of India are showing better recovery than the world average. Except West Bengal and Gujarat all other states have less fatality rate than world average.

\section{Acknowledgement}

We would like to express our special thanks of gratitude to Sardar Bhagwan Singh University who gave us the golden opportunity to do this wonderful research work on the topic Understanding Behaviour Of Corona Virus In India And In Uttarakhand which also helped us in doing a lot of related research and we came to know about so many new concepts. We are really thankful to them.

\section{References}

1.Van der Hoek, L., Pyrc, K., Jebbink, M. F., Vermeulen-Oost, W., Berkhout, R. J., Wolthers, K. C., \&Berkhout, B. (2004). Identification of a new human coronavirus. Nature medicine, 10(4), 368-373.

2. Peiris, J. S. M., Lai, S. T., Poon, L. L. M., Guan, Y., Yam, L. Y. C., Lim, W., \& Cheng, V. C. C. (2003). Coronavirus as a possible cause of severe acute respiratory syndrome. The Lancet, 361(9366), 1319-1325.

3. Tang, X., Li, G., Vasilakis, N., Zhang, Y., Shi, Z., Zhong, Y., \& Zhang, S. (2009). Differential stepwise evolution of SARS coronavirus functional proteins in different host species. BMC evolutionary biology, 9(1), 52.

4. Hurst, K. R., Kuo, L., Koetzner, C. A., Ye, R., Hsue, B., \& Masters, P. S. (2005). A major determinant for membrane protein interaction localizes to the carboxy-terminal domain of the mouse coronavirus nucleocapsid protein. Journal of virology, 79(21), 1328513297.

5. De Haan, C. A., Smeets, M., Vernooij, F., Vennema, H., \&Rottier, P. J. M. (1999). Mapping of the coronavirus membrane 
protein domains involved in interaction with the spike protein. Journal of virology, 73(9), 7441-7452.

6. Booth, C. M., Matukas, L. M., Tomlinson, G. A., Rachlis, A. R., Rose, D. B., Dwosh, H. A., \&Ephtimios, I. E. (2003). Clinical features and short-term outcomes of 144 patients with SARS in the greater Toronto area. Jama, 289(21), 2801-2809.
7. Yang, P., Liu, P., Li, D., \& Zhao, D. (2020). Corona Virus Disease 2019, a growing threat to children? The Journal of infection.

8. Onder, G., Rezza, G., \&Brusaferro, S. (2020). Case-fatality rate and characteristics of patients dying in relation to COVID-19 in Italy. Jama, 323(18), 1775-1776.

\section{How to cite this article:}

Abhinav Gaur, Om Prakash, Hem C Joshi, Ajay Kumar, Anil Verma, S. K. Guru and Shyam N. Nautiyal. 2020. Overview of Coronavirus Behaviour in Hill State Uttarakhand and Most Affected States in India. Int.J.Curr.Microbiol.App.Sci. 9(07): 3078-3088.

doi: https://doi.org/10.20546/ijcmas.2020.907.363 